\title{
Kesantunan Berbahasa dalam Interaksi Akademik di Fakultas Sastra UAI
}

\author{
Lusi Lian Piantari ${ }^{1}$, Era Bawarti ${ }^{2}$ \\ ${ }^{1,2}$ Program Studi Sastra Inggris, Fakultas Sastra, Universitas Al Azhar Indonesia \\ Kompleks Masjid Agung Al Azhar Jl. Sisingamangaraja Kebayoran Baru Jakarta Selatan 12110 \\ Penulis untuk Korespondensi/E-mail: lusi_lian@uai.ac.id, era.sugiri@uai.ac.id
}

\begin{abstract}
Abstrak - Penelitian ini membahas strategi kesantunan yang digunakan oleh dosen ketika melakukan bimbingan skripsi dengan mahasiswa. Hasil analisis yang dilaporkan dalam penelitian ini adalah tipe strategi kesantunan yang digunakan oleh dosen ketika memproduksi tuturan yang mengandung tindakan mengancam muka (Face Threatening Acts) kepada mahasiswa. Data diperoleh secara natural dari percakapan antara seorang dosen dan dua mahasiswa pada saat proses bimbingan skripsi. Tuturan yang mengandung tindakan mengancam muka yang dianalisis dalam penelitian ini adalah pada saat dosen meminta siswa untuk melakukan sesuatu. Data percakapan direkam secara audio untuk dianalisis berdasarkan teori strategi kesantunan dan konsep muka Brown \& Levinson (1987) dan tipe permintaan (request) Blum Kulka \& Olshtain (1984). Hasil penelitian menunjukkan permintaan yang dituturkan oleh dosen dilakukan dengan tiga tipe strategi yaitu secara eksplisit (bald-on record), menggunakan strategi kesantunan positif yang meliputi claim common ground, hedge opinion, dan avoid disagreement dan gabungan antara strategi kesantunan positif dan negatif. Relasi kuasa antara dosen dan mahasiswa juga merupakan faktor penting dalam penggunaan strategi kesantunan.
\end{abstract}

Kata kunci - strategi kesantunan, konsep muka, permintaan, relasi kuasa

Abstract - This research discusses the politeness strategy used by lecturers when doing thesis guidance with students. The result of analysis reported in this research is the type of politeness strategy used by the lecturer when producing speech that contains Face Threatening Acts to the students. The data obtained naturally from the conversation between a lecturer and two students during the process of thesis tutoring. The words that contain the face-threatening actions analyzed in this study is when the lecturer asks the student to do something. The conversation data was recorded by audio for analysis based on the politeness strategy and concept of Brown \& Levinson face (1987) and Blum Kulka \& Olshtain (1984). The result of the research shows that the demand given by the lecturer is done with three types of strategy that is explicitly (bald-on record), using positive politeness strategy which includes common ground claim, hedge opinion, and avoid disagreement and combination between positive and negative politeness strategy. The power relations between lecturers and students is also an important factor in the use of politeness strategies.

Keywords - strategy of unity, concept advance, demand, power relations

\section{PENDAHULUAN}

$I$ nteraksi memiliki dua aspek utama yaitu pertukaran informasi dan hubungan antar personal di antara para pelaku interaksi. Hubungan yang baik di antara para pelaku interaksi ini (penutur: orang yang bertutur dan petutur: orang yang mendengarkan tuturan) merupakan salah satu aspek utama yang dapat membuat suatu komunikasi atau interaksi menjadi berhasil dan bermakna. Hubungan antar personal ini mencakupi cara bertutur 
partisipan interaksi, hubungan antara penutur dan petutur. Dalam linguistik, terdapat sebuah konsep yang berperan penting dalam aspek hubungan antar penutur dan pendengar ini, yang dikenal dengan istilah Kesantunan (politeness). Kehidupan akademik kampus, merupakan sebuah wacana yang sangat banyak melibatkan pola interaksi. Salah satu pola interaksi yang menarik untuk dikaji secara linguistik adalah interaksi antara dosen dan mahasiswa. Hubungan dosen dan mahasiswa pada dasarnya adalah hubungan yang asimetris. Dosen adalah posisi yang memiliki kuasa lebih dibanding dengan mahasiswa. Pada sebagian besar interaksi yang terjadi antara dosen dan mahasiswa terjadi "ketidakseimbangan". Oleh karena itu pada interaksi antara dosen dan mahasiwa, kedua belah pihak menggunakan berbagai strategi, diantaranya adalah strategi kesantunan, yang diharapkan dapat memfasilitasi kedua belah pihak untuk dapat mencapai keberhasilan dalam sebuah komunikasi.

\section{TINJAUAN PUSTAKA}

'Kesantunan' pada hakikatnya adalah tentang 'apa yang dikatakan, dan bukan tentang apa yang dipikirkan atau diyakini' (Cruse 2000:362). Menurut Leech (1977 dalam Cruse 2000:362), kesantunan memiliki prinsip yakni minimize the expression of impolite beliefs, yang oleh Cruse (2000:362) didefinisikan sebagai choosing expressions which minimally belittle the hearer's status, atau dengan kata lain causing the minimum loss to the hearer's face. Kata face (wajah) di atas dapat dirujukkan pada konsep face berdasarkan teori kesantunan Brown-Levinson (1978) yang menyempurnakan apa yang sudah dikonsepkan oleh Goffman (1967), yakni 'perasaan setiap individu tentang self-worth (harga diri) atau self-image (citra diri)' (lihat Thomas 1997:169). Harga diri atau citra diri inilah yang kerapkali dirusak (damaged), harus dipelihara (maintained), dan dapat ditingkatkan (enhanced) karena atau melalui interaksi dengan orang lain (Thomas 1997:169).

Face memiliki dua aspek: positif, yang merefleksikan keinginan seseorang untuk disukai, disetujui/disepakati, dihargai, dan diapresiasi oleh orang lain; dan negatif, yang merefleksikan keinginan seseorang untuk, sebaliknya, tidak diganggu atau dibebani sesuatu, serta untuk memiliki kemerdekaan guna melakukan apa yang dikehendakinya (Brown-Levinson, lihat Thomas 1997:169).

Dikaitkan dengan kesantunan dalam berkomunikasi, ada konsep penting yang harus dipraktekkan, yakni 'strategi'. 'Strategi' menjadi hal penting karena dalam berkomunikasi diakui ada tuturan (atau tulisan) yang berpotensi mengancam muka yang disebut tindak tutur pengancam muka (face threatening act-FTA) (Brown-Levinson, lihat Gunarwan 2007:158). Jika seorang penutur memilih untuk menggunakan tindak tutur yang tidak mengancam muka lawan bicaranya, maka terdapat dua strategi kesantunan yang dapat digunakan, yaitu strategi kesantunan positif dan strategi kesantunan negatif (Brown \& Levinson, 1987).

Strategi kesantunan positif membuat penutur dapat menyampaikan maksudnya dengan cara menunjukkan tujuan tuturannya. Sedangkan strategi kesantunan negatif mengarahkan penutur (penulis) untuk tidak mengganggu atau tidak membebani petutur (pembaca) dengan sesuatu serta membiarkan petutur (pembaca) melakukan apa yang dikehendakinya (disimpulkan dari Yule 2006:111-116).

\section{METODE PENELITIAN}

Penelitian ini merupakan suatu studi kasus yang bersifat kualitatif dengan ancangan analisis wacana. Strategi yang dianalisis secara kualitatif adalah: bald on record, kesantunan positif (positive politeness), dan gabungan antara kesantunan positif dan negatif (Brown dan Levinson, 1987). Data diperoleh melalui interaksi antara mahasiswa dan dosen dalam pembimbingan skripsi. Data diambil dari satu orang dosen di Fakultas Sastra UAI (1 dosen Prodi Sastra Inggris dan dua orang mahasiswa dari Prodi Sastra Inggris. Dosen tersebut berjenis kelamin perempuan dengan usia 29 tahun. Sementara kedua mahasiswa terdiri dari satu perempuan dan satu laki-laki. Partisipan merupakan mahasiswa semester 10 yang sedang melakukan penulisan skripsi. Data berupa tuturan antara mahasiswa dan dosen yang mengandung strategi kesantunan berbahasa. Strategi kesantunan berbahasa yang akan diteliti adalah tuturan dengan strategi 
kesantunan yang berasal dari dosen terhadap mahasiswa. Pengambilan data dilakukan sebanyak dua kali terhadap satu orang dosen Prodi Sastra Inggris dan dua orang mahasiswa Prodi Sastra Inggris.

Data yang berupa percakapan akan direkan dengan menggunakan dua moda alat perekam yaitu perekam suara dan kamera perekam suara dan gambar secara digital. Kedua alat perekan itu digunakan untuk mendapatkan hasil rekaman suara dan gambar yang baik. Perekaman akan dilakukan pada tiga kali masa bimbingan skripsi dari masing-masing pasangan interaksi. Hasil rekaman tersebut ditranskripsikan menggunakan konvensi GAT (Selting et al., 1998). Tuturan dari hasil transkripsi percakapan tersebut akan diklasifikasi berdasarkan jenis strategi kesantunan berbahasa yaitu bald on record, kesantunan positif (positive politeness), dan gabungan antara kesantunan positif dan negatif, (Brown dan Levinson, 1987) dan konsep muka yang dimunculkan oleh kedua penutur: konsep muka positif dan negatif (Brown dan Levinson, 1987). Strategi kesantunan berbahasa tersebut ditandai oleh tindak tutur (speech acts) tertentu yang menentukan apakah kesantunan diterapkan atau tidak.

\section{HASIL DAN PEMBAHASAN}

\section{Strategi Kesantunan Penutur dalam Interaksi Akademik}

Strategi kesantunan yang digunakan oleh dosen dalam interaksi akademis pembimbingan skripsi adalah strategi kesantunan positif. Strategi ini berusaha untuk mendekatkan jarak antara penutur (dosen) dan lawan bicaranya (mahasiswa) dengan cara menunjukkan solidaritas dan hubungan yang memiliki relasi kuasa yang tidak terlalu jauh (pertemanan). Data penelitian ini menunjukkan bahwa penutur (dosen) menggunakan ragam bahasa yang informal ketika berinteraksi dengan lawan bicaranya (mahasiswa). Penggunaan ragam bahasa informal ini dimaksudkan untuk membuat suasana interaksi akademis tersebut lebih nyaman dan muka lawan bicara (mahasiswa) lebih dapat dijaga pada saat penutur menyampaikan permintaan atau perintah.

Tipe strategi kesantunan positif yang digunakan oleh penutur pada interaksi mencakupi claim common ground dan kerjasama antara Penutur (Speaker) dan Lawan Bicara (Hearer). Strategi claim common ground meliputi: attend to Hearer, avoid disagreement, dan hedge opinions. Sedangkan strategi kerjasama antara Penutur dan Lawan Bicara meliputi pemberian alasan. Selain menggunakan strategi kesantunan positif, penutur juga menggunakan strategi bald on record (pernyataan eksplisit) dalam menyampaikan tindak tutur. Strategi kesantunan yang digunakan oleh penutur dalam menuturkan permintaannya dirangkum dalam tabel berikut ini:

Tabel 1. Tipe strategi kesantunan penutur dalam interaksi

\begin{tabular}{|c|c|c|}
\hline No & $\begin{array}{l}\text { Strategi } \\
\text { kesantun- } \\
\text { an }\end{array}$ & Substrategi kesantunan \\
\hline 1. & $\begin{array}{l}\text { Strategi } \\
\text { kesantun- } \\
\text { an positif }\end{array}$ & $\begin{aligned} \text { Claim common ground } \\
-\quad \text { Attend to Hearer } \\
-\quad \text { Avoid } \\
\text { disagreement } \\
\text { - } \quad \text { Hedge opinions } \\
\text { Kerjasama antara Penutur } \\
\text { dan Lawan Bicara } \\
\text { - } \quad \text { Pemberian alasan } \\
\text { - } \quad \text { Menunjukkan } \\
\quad \text { keoptimisan }\end{aligned}$ \\
\hline 2. & $\begin{array}{l}\text { Bald on } \\
\text { record } \\
\text { (eksplisit) }\end{array}$ & $x_{0}$ \\
\hline
\end{tabular}

\section{Strategi Kesantunan Positif}

Strategi kesantunan yang banyak digunakan oleh dosen dalam meminta mahasiswa utuk melakukan sesuatu dalam konteks bimbingan skripsi adalah strategi kesantunan positif. Strategi kesantunan positif ini merupakan salah satu strategi yang dilakukan penutur sebagai upaya untuk menghargai muka positif dari lawan bicara (Brown dan Levinson, 1987). Data pada penelitian ini menunjukkan bahwa strategi kesantunan positif yang dilakukan oleh dosen terhadap mahasiswa sangat dipengaruhi oleh relasi kuasa antara mereka. Dosen yang memiliki kuasa lebih dibandingkan dengan mahasiswa memungkinkan adanya interaksi yang lebih cair dan akrab antara dosen dengan mahasiswa.

Strategi kesantunan positif dengan cara claim common ground yang ditemukan pada data adalah attend to Hearer, avoid disagreement, dan hedge opinions. Melalui strategi ini, 
penutur (dosen) menunjukkan kuasanya melalui pemilihan situasi percakapan. Salah satu strategi yang digunakan oleh penutur dalam meminta lawan bicara melakukan sesuatu adalah dengan memperhatikan keinginan atau kebutuhan lawan bicara (attend to Hearer):

(1) D : kecuali kalau ini secara umum gak papa, cuman kalau ada definisi tertentu, halaman tolong disebutin, yang kayak gini nih. in the memes berarti ya, bukan dia artikel. Gak usah artikel related to a few memes, langsung aja collects memes aja. A few memes, Ini juga jangan dimiringin

Penutur meminta dengan cara suggestory formulae yaitu memberikan saran secara langsung kepada lawan bicara. Walaupun saran yang disampaikan secara konten langsung pada pokok permasalahan, akan tetapi penutur tidak menyampaikannya dengan menambahkan beberapa kalimat yang dapat menurunkan tingkat tekanan dari permintaan tersebut. Selain suggestory formulae, permintaan pada data ini juga menggunakan hedge opinions dengan beberapa penggunaan kata-kata yang menunjukkan penurunan tingkat permintaan (gak papa, tolong, ya). Dari situasi percakapan ini dapat dilihat bahwa penutur (dosen) berusaha untuk memperkecil relasi kuasa dan jarak sosial di antara dosen dan mahasiswa. Jarak sosial yang jauh biasanya membutuhkan situasi yang lebih formal. Penutur (dosen) berusaha untuk memberitahu dan memerintahkan mahasiswa dengan tidak terlalu menekankan bentuk perintahnya.

Selain itu, kuasa yang dimiliki oleh dosen menyebabkan dosen dapat meminta mahasiswa untuk melakukan sesuatu dengan cara obligation statement. Kata kerja bantu modalitas seperti harus dan perlu, digunakan oleh dosen untuk menentukan tingkat permintaan. Contoh pada data berikut menunjukkan penggunaan kata kerja bantu modalitas yang memiliki makna keharusan:

(2) D: kamu eeh perlu diperbaiki ya ada kesalahan berulang saya gak teliti gitu kamu ngebahas sendiri, soalnya kan bisa di satu-satu juga di..

(3) D: ya berarti speech actnya dulu, kamu jelaskan mau...perlu kamu jelaskan ini untuk menjelaskan kemarahan tipe apa gitu
Penutur juga menuturkan permintaannya dengan dengan strategi avoid disagreement (menghindari ketidaksetujuan). Strategi tersebut dilakukan untuk menghindari tindakan mengancam muka (Face Threatening Acts) yang mungkin saja dilakukan oleh penutur pada saat menyampaikan permintaannya. Data berikut ini merupakan contoh dari strategi kesantunan dengan menggunakan avoid disagreement:

(4) D : Enggak papa, tapi kan setelah kamu bilang, not important progress, not always something, kamu ini disini pengen berargumen bahwa gak seтua hinaan, polite atau gimana, kalau pengen ini ya diubah saja

(5) D : kan kalau direct speech act itu biasanya sudah masuk di pembahasan speech act, kayak I apologize, apologize nya itu kan, tuturannya langsung, jadi gak usah dibahas langsung ke indirect speech act itu apa sih, kenapa harus dibedakan dengan speech act biasa

Kedua contoh di atas menggambarkan keadaan di mana penutur sebenarnya tidak setuju dengan apa yang telah dikerjakan oleh lawan bicara (mahasiswa), namun penutur terlihat tidak ingin mengatakannya secara langsung.

\section{Kerjasama Antara Penutur dan Lawan Bicara}

Strategi kesantunan positif lainnya yang ditunjukkan oleh penutur adalah dengan menunjukkan kerjasama antara penutur dan lawan bicaranya.

(6) D: Dimiringin itu cuman kalau nyebut judul skripsinya saja. Sudah gak papa, kalau ada kesalahan grammar yang berulang tolong dibenerin ya,

(7) D: kayaknya grammarnya salah tolong dibenerin lagi, kalau dari buku dikutip juga,bukunya Peirce yaa

Yang dimaksud dengan kerjasama di sini adalah penutur mempertimbangkan muka dari lawan bicara ketika tindak tutur meminta itu diucapkan. Seperti data pada contoh di atas, penutur berusaha untuk menetralisir keadaan dengan menggunakan frasa "sudah gak papa" walaupun lawan bicara (mahasiswa) telah membuat kesalahan. Pada contoh kedua, 
penutur berusaha untuk secara tidak langsung menunjukkan kesalahan yang dibuat oleh lawan bicara dengan menggunakan kata yang menunjukkan ketidakyakinan (kayaknya). Untuk mengurangi tekanan pada tindak tutur permintaan yang disampaikan, penutur seringkali memberikan alasan kepada lawan bicara. Hal ini dimaksudkan agar lawan bicara bisa memahami mengapa dia harus melakukan permintaan yang disampaikan oleh penutur.

Penutur juga menunjukkan strategi kesantunan positif dengan menunjukkan keoptimisan terhadap apa yang telah dilakukan oleh lawan bicara:

(8) D : ya jadi kamu, bagi dulu direct speech act seтиa, disini dari, setelah kamu bahas, konteksnya dulu dibahas, ini bener bagu jelasin konteksnya, terus kamu sudah bilang.. dari

Contoh di atas menggambarkan bagaimana penutur (dosen) menunjukkan keoptimisan kepada lawan bicara (mahasiswa), walaupun sebenarnya isi tuturan penutur adalah permintaan kepada lawan bicara untuk melakukan sesuatu.

\section{Bald on Record}

Strategi yang digunakan oleh penutur dalam memberikan perintah juga dilakukan secara eksplisit. Berdasarkan teori kesantunan Brown dan Levinson (1987), strategi dalam menuturkan sebuah tindak tutur juga dapat dilakukan secara bald on record (eksplisit) yaitu menuturkan secara langsung apa yang dimaksud. Dalam konteks percakapan antara dosen dan mahasiswa dalam penelitian ini, strategi ini juga ditemukan pada beberapa contoh:

(9) D: kamu agak masukin aja ke dalem. Gak usah pake penggarisan atau kayaknya kalau, kamu langsung set numbering langsung

(10) D: tambahin, karena itu kan yang penting dari pertanyaan penelitian kamu

Kedua contoh di atas menunjukkan bahwa penutur menggunakan strategi bald on record dalam mengajukan permintaannya. Namun, penutur tetap mempertahankan situasi informal dalam interaksinya dengan lawan bicara. Hal tersebut terlihat dari penggunaan ragam bahasa yang cenderung tidak formal seperti penggunaan bahasa sehari-hari (gak usah, tambahin) yang membuat suasana percakapan menjadi cair walaupun tindak tutur yang diucapkan adalah tindak tutur direktif yang biasanya membutuhkan situasi formal untuk keberhasilan tuturan tersebut. Penutur juga memberikan alasan mengapa permintaan tersebut perlu dilakukan oleh lawan bicaranya. Larangan untuk tidak atau jangan melakukan sesuatu juga dituturkan oleh penutur secara eksplisit, seperti beberapa contoh di bawah ini:

\section{(11) D : jangan satu kalimat \\ (12) D : dimiringin gak papa, tapi jangan di bold}

Dalam interaksi yang menunjukkan permintaan dilakukan secara eksplisit, menggambarkan dengan jelas relasi kuasa yang muncul dalam situasi percakapan antara penutur (dosen) dan lawan bicara (mahasiswa). Penutur memiliki tingkat kuasa yang lebih dibandingkan dengan lawan bicara, sehingga penutur dapat secara eksplisit menuturkan permintaan, perintah, maupun larangan. Lawan bicara, dalam hal ini mahasiswa memiliki tingkat kuasa yang lebih rendah dibanding penutur (dosen) sehingga dalam interaksi tidak ditemukan argumen yang secara eksplisit menyangkal atau menolak tuturan permintaan yang diucapkan oleh penutur

\section{KESIMPULAN}

Hasil penelitian menunjukkan walaupun relasi kuasa yang dimiliki antara dosen dan mahasiswa tidak setara, namun dosen yang bertindak sebagai penutur selalu berusaha untuk menjaga muka lawan bicara (mahasiswa) pada saat menyampaikan tindak tutur permintaan. Strategi kesantunan yang digunakan untuk menjaga muka lawan bicara tersebut adalah strategi kesantunan positif, yaitu penutur berusaha untuk menunjukkan keinginannya dengan sikap solidaritas, pertemanan, dan keakraban. Hal tersebut ditunjukkan oleh bahasa yang digunakan oleh penutur yaitu ragam bahasa informal. Ragam bahasa tersebut membuat suasana percapakapan menjadi lebih cair dan tujuan dari tindak tutur penutur dapat disampaikan dan dipahami oleh lawan bicara dengan baik.

Strategi kesantunan positif yang dilakukan oleh penutur pada penelitian ini meliputi strategi 
claim common ground, kerjasama antara penutur dan lawan bicara, dan strategi bald on record. Strategi kesantunan positif lebih banyak digunakan oleh penutur dibandingkan dengan strategi bald on record. Hal ini menunjukkan bahwa tingkat kuasa yang lebih dimiliki oleh penutur membuatnya lebih leluasa untuk menentukan strategi kesantunan yang bagaimana yang akan dia gunakan.

\section{DAFTAR PUSTAKA}

[1] Dornyei, Z. Research methods in applied linguistics: Quantitative, Qualitative, and Mixed Methodologies. Oxford: Oxford University Press. 2007.

[2] Gutierrez, K.D. Unpacking Academic Discourse. Discourse Processes, 19, 2137.1995.

[3] Halliday, M.A.K., \& Ruqaiya Hassan.Cohesion in English. London: Longman.

[4] Hofmann, Th. R. 1993. Realms of Meaning: An Introduction to Semantics. NY: Longman. 1976.

[5] Leech, G. Principles of Pragmatics. London, New York: Longman Group Ltd. 1983.
[6] Renkema, Jan. Introduction to Discourse Studies. Amsterdam: John Benjamins. Selting, M., et al. 1998. Gesprächsanalytische Transkriptionssystem (GAT). In Linguistische Berichte 173, S. 91-122. 2004.

[7] Tallerman, Maggie. Understanding Syntax. New York: Oxford University Press. 1998.

[8] Thomas, Jenny. Meaning in Interaction: an Introduction to Pragmatics. London: Longman. 1997.

[9] Yule, George. Pragmatik (terj. Indah Fajar Wahyuni). Yogyakarta: Pustaka Pelajar. 2006.

[10] Maybin, Janet. "Language, Struggle and Voice: The Bakhtin/Volosinov Writings", dalam Margaret Wetherell, Stephanie Taylor, Simeon Yates (eds.). 2002. Discourse Theory and Practice: A Reader. London: Sage Publications. 2002.

[11] Wilson, Deirdre, \& Dan Sperber.1986. "Inference and Implicature", dalam Davis Steven (ed.). Pragmatics: A Reader. Oxford: Oxford University Press. 1991. 